\title{
Wybrane właściwości złączy spawanych stali S700 MC wykonanych metodą hybrydową plazma+MAG
}

\author{
Selected properties of plasma+MAG welded joints \\ of S700 MC steel
}

\begin{abstract}
Streszczenie
Celem niniejszej pracy jest zbadanie wpływu energii liniowej na właściwości złączy spawanych wykonanych metodą hybrydową Plazma+MAG ze stali S700 MC (o wysokiej granicy plastyczności $R_{e}=700 \mathrm{MPa}$ ). W ramach badań wykonane zostały spawane złącza próbne blach ze stali obrabianej termomechanicznie dla różnych wartości m.in. energii liniowej spawania. W celu zweryfikowania jakości oraz właściwości otrzymanych złączy, przeprowadzono badania niszczące, pomiary twardości oraz próby właściwości mechanicznych złączy.
\end{abstract}

Słowa kluczowe: spawanie hybrydowe Plazma+MAG; stal o wysokiej wytrzymałości; S700 MC; stal termomechaniczna; energia liniowa spawania; badania niszczące

\begin{abstract}
The purpose of this paper is to investigate the influence of heat input on the properties of welded joints produced by the Plasma+MAG method of S700 MC (high strength $\mathrm{R}_{\mathrm{e}}=700 \mathrm{MPa}$ ). Welded joints of thermomechanical steel have been made with different values of heat input. Due to the verification of the quality and properties of the obtained joints, destructive tests, hardness measurements and mechanical properties of joints were performed.
\end{abstract}

Keywords: Plasma+MAG hybrid welding; high strength steel; thermomechanical steel; heat input; destructive testing

\begin{abstract}
Wstęp
Do budowy konstrukcji spawanych coraz częściej stosowane są nowoczesne materiały konstrukcyjne o podwyższonej wytrzymałości, które łączy się również nowymi wysokowydajnymi hybrydowymi metodami spawania. W pracy została wykorzystana nowoczesna metoda hybrydowego spawania Plazma+MAG (scharakteryzowana w pracach $[6,7,9])$ charakteryzująca się wysoką koncentracją ciepła w miejscu łączonych elementów, dzięki czemu możliwe jest wykonanie pełnowartościowych złączy o stosunkowo niedużej szerokości spoiny i dużej wysokości. W celu zbadania wpływu wartości energii liniowej na własności mechaniczne złączy doczołowych (stali S700 MC) zostały one poddane badaniom niszczącym. Praca przedstawia wyniki oraz analizę przeprowadzonych badań metalograficznych (makro- i mikroskopowych), pomiarów twardości oraz badań właściwości mechanicznych tj. statycznej próby rozciągania i zginania oraz próby udarności.
\end{abstract}

\section{Stal obrabiana termomechanicznie o wysokiej granicy plastyczności}

Obróbka cieplno-plastyczna jest najbardziej efektywnym sposobem poprawy właściwości mechanicznych, ponieważ uzyskuje się jednoczesne zwiększenie granicy plastyczności, polepszenie ciągliwości i spawalności przy równoczesnym stosowaniu w stali relatywnie małej ilości dodatków stopowych. Najkorzystniejszymi mechanizmami umocnienia stali wysokowytrzymałych są rozdrobnienie ziarna, utwardzenie wydzieleniowe i utwardzenie dyslokacyjne $[1 \div 4]$. W celu obniżenia kosztów produkcji tego rodzaju stali przy zachowaniu ich wysokich właściwości wytrzymałościowych bez znacznego pogorszenia spawalności, zaczęto wytwarzać stale konstrukcyjne z mikrododatkami oraz stosować procesy dodatkowo zwiększające wytrzymałość. Przykładem tak otrzymywanych materiałów są stale walcowane termomechanicznie. Rozpiętość granicy plastyczności i wytrzymałości na rozciąganie produkowanych obecnie stali

Mgr inż. Beata Skowrońska; dr hab. inż. Tomasz Chmielewski, prof. PW; dr hab. inż. Dariusz Golański, prof. PW - Politechnika Warszawska; mgr inż. Jacek Szulc - SupraElco.

Autor korespondencyjny/Corresponding author: be.skowronska@gmail.com 
o podwyższonej wytrzymałości jest bardzo duża. Znane są już stale o $R_{e}=1850 \mathrm{MPa}$. Zastosowanie stali o wysokiej granicy plastyczności umożliwia zarówno zmniejszenie masy konstrukcji jak i zużycia stali. Elementy konstrukcji wykonane ze stali o podwyższonej wytrzymałości w stosunku do elementów ze zwykłej stali konstrukcyjnej mogą przenosić te same obciążenia przy mniejszych przekrojach.

Ogólnie przy spawaniu stali drobnoziarnistych wysokowytrzymałych należy zwrócić uwagę na stosowanie właściwych materiałów dodatkowych do spawania, zawierających składniki stopowe, które zapewniają odpowiedni poziom właściwości wytrzymałościowych spoiny w stosunku do materiału rodzimego. Warunki stygnięcia oraz wartość energii liniowej procesu spawania mają również znaczący wpływ na strukturę SWC oraz spoiny. Przy dużych prędkościach chłodzenia typową strukturą SWC stali obrabianych termomechanicznie jest bainit dolny, wykazujący zadowalającą odporność na pękanie kruche. Jednak wprowadzenie dużej ilości ciepła do złącza spawanego wydłuża czas wytrzymania SWC w wysokiej temperaturze i obniża prędkość chłodzenia. Prowadzi to do rozrostu ziarna austenitu i w konsekwencji powstania, szczególnie w strefie przyległej do linii wtopienia struktury o gorszych właściwościach plastycznych tj. wąskokątowych granic między listwami górnego i dolnego bainitu oraz faz martenzytyczno-austenitycznych.

Cykl cieplny spawania stali obrabianych termomechanicznie, może wywołać następujące problemy:

- pęknięcia gorące krystalizacyjne i segregacyjne;

- pęknięcia zimne wodorowe w SWC i w spoinie;

- pękanie lamelarne;

- pękanie korozyjne w kwaśnych gazach;

- zmiękczenie SWC w wyniku spawania (problem „warstwy miękkiej");

- nieosiąganie wymaganego poziomu udarności w spoinie i w SWC (kruchość spowodowana utwardzeniem wydzieleniowym, niekorzystna struktura).

Podczas spawania stali obrabianych termomechanicznie w strefie wpływu ciepła powstaje obszar o zmiękczonej mikrostrukturze, który ma gorsze właściwości wytrzymałościowe. Osłabienie to jest jeszcze wyraźniej widoczne, gdy po procesie kontrolowanego walcowania stosowano przyspieszone chłodzenie lub walcowanie odbywało się w zakresie temperatury $\mathrm{Ac}_{3}-\mathrm{Ac}_{1}$ (wówczas uzyskana mikrostruktura mogła powstać częściowo przez umocnienie zgniotem). Spawanie z ograniczoną mocą liniową łuku sprawia, że „warstwa miękka” jest wąska.

Stal S700 MC charakteryzuje się silnie zdefektowaną, nierównowagową strukturą bainityczno-ferrytyczną, która jest utwardzona wydzieleniowo, roztworowo oraz przez zgniot i rozdrobnienie ziarna. W wyniku spawania dochodzi do zmian dyspersji i rozpadu faz umacniających, które w trakcie stygnięcia wydzielają się ponownie w obszarze SWC i spoiny, lecz w sposób niekontrolowany. W obszarze strefy wpływu ciepła zachodzą również procesy starzeniowe.

Podstawowe problemy, jakie pojawiają się podczas procesu spawania stali obrabianych termomechanicznie to:

- utrata właściwości nabytych w trakcie obróbki cieplnoplastycznej w wyniku oddziaływania cyklu cieplnego spawania, który może powodować częściowe rozpuszczenie drobnodyspersyjnych wydzieleń umacniających (węgliki, węglikoazotki $\mathrm{Nb}, \mathrm{Ti}, \mathrm{V}$ ) i ich ponowne niekontrolowane wydzielanie;

- nadmierny rozrost wydzieleń umacniających i utrata ich zdolności hamowania rozrostu ziarna;

- przechodzenie mikrododatków stopowych podczas spawania do spoiny oraz różnica w równoważniku węgla pomiędzy materiałem rodzimym a spoiną.

Odpowiednie sterowanie procesem spawania może ograniczyć skalę ich wystąpienia.

\section{Charakterystyka spawania hybrydowego Plazma+MAG}

Połączenie spawania plazmowego i MAG pozornie nie spełnia „warunku hybrydy" o stosowaniu dwóch różnych pod względem źródła ciepła metod spawania, ponieważ obydwa źródła ciepła bazują na łuku elektrycznym. Jednak te dwa podobne źródła energii spawania, w różny sposób przekazują ciepło do materiału spawanego. Sposób nagrzewania materiału rodzimego $\mathrm{w}$ metodzie MAG ma charakter przewodnościowy, a w przypadku łuku plazmowego w wysokim stopniu zjonizowanego o wysokiej temperaturze i gęstości mocy umożliwiającej powstanie kanału parowego, ciepło przekazywane jest do materiału spawanego w głównej mierze poprzez bombardowanie elektronami anody (ale mechanizm przewodnościowy również funkcjonuje). W przypadku łuku plazmowego przekazanie ciepła do materiału rodzimego ma charakter gwałtowny i następuje w wyniku pochłaniania energii strumienia elektronów na skutek zderzeń elektronów z siecią krystaliczną materiału. Poziom energii kinetycznej elektronów zamienianej w energię cieplną na skutek zderzenia, zależy od stopnia jonizacji i wartości napięcia przyśpieszającego.

Niskotemperaturowa plazma stosowana jest często w napawaniu modyfikacyjnym i regeneracyjnym powierzchni części maszyn. W technice z otwartym kanałem parowym wykorzystywana jest także do spawania grubych elementów konstrukcyjnych $[7,9]$. Cechą charakterystyczną tej techniki jest (przy odpowiednio dobranej synchronizacji czasu narastania natężenia prądu spawania i natężenia przepływu gazu plazmowego) rozwijające się zagłębienie tzw. kanału parowego (kapilary). Utworzenie kanału parowego jest możliwe, gdy moc jednostkowa łuku plazmowego wynosi powyżej $10^{10} \mathrm{~W} / \mathrm{m}^{2}$. Głębokość kapilary odpowiada pełnej penetracji materiału i część łuku plazmowego jest widoczna od strony grani. W procesie spawania plazmowego taką techniką, ciepło przekazywane jest do materiału spawanego na całej długości kapilary (a nie od powierzchni jak to ma miejsce w przypadku spawania techniką z jeziorkiem) [5].

Schemat budowy plazmotronu hybrydowego został przedstawiony na rysunku 1.

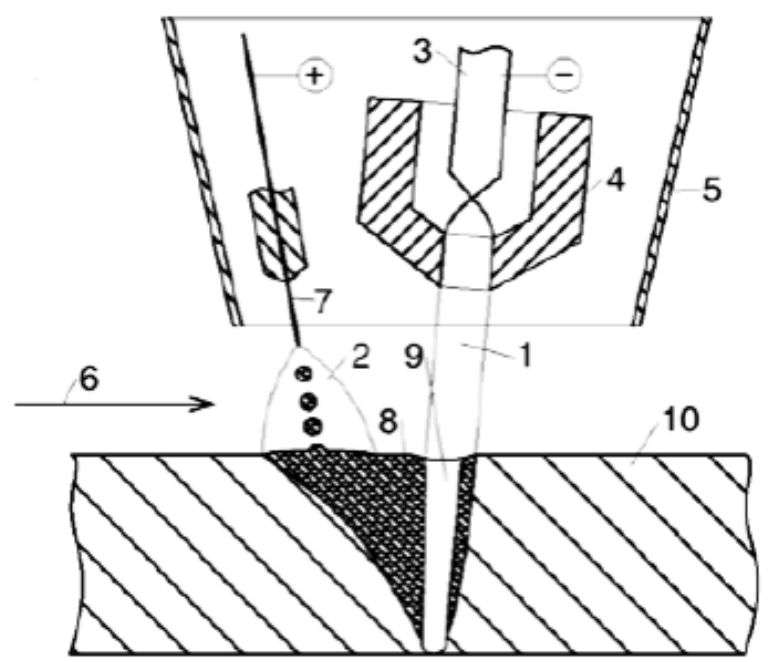

Rys. 1. Schemat budowy plazmotronu hybrydowego: 1 - łuk plazmowy, 2 - łuk GMA, 3 - katoda plazmotronu, 4 - dysza plazmowa, 5 - wspólna dysza gazu osłonowego, 6 - kierunek spawania, 7 - drut elektrodowy GMA, 8 - ciecz metaliczna, 9 - kanał parowy, 10 - materiał podstawowy [6]

Fig. 1. Schematic diagram of the hybrid plasmatron: 1 - plasma arc, 2 - GMA arc, 3 - plasmatron cathode, 4 - plasma nozzle, 5 - common shielding gas nozzle, 6 - welding direction, 7 - GMA wire electrode, 8 - liquid metal, 9 - plasma keyhole, 10 - substrate material [6] 
Mała ilość cieczy metalicznej powstającej za przemieszczającym się łukiem plazmowym, będącą efektem intensywnego parowania metalu oraz minimalnego, ale jednak odstępu brzegów spawanych elementów, powodowałaby wklęsłe lico. Problem ten został wyeliminowany poprzez zastosowanie swobodnie jarzącego się w przestrzeni między elektrodami łuku GMA. Łuk GMA oddziałuje na jeziorko spawalnicze tuż za łukiem plazmowym, jeszcze przed skrystalizowaniem cieczy powstałej na skutek działania plazmy, a masa topionego spoiwa służy do formowania lica spoiny. Poprzez materiał dodatkowy, można również wpływać na skład chemiczny [6 $\div 10]$.

W związku z wykorzystaniem jednocześnie dwóch, oddzielnych źródeł ciepła $Q_{1}$ - ciepło dostarczane z łuku plazmowego oraz $Q_{2}$ - ciepło dostarczane z łuku elektrycznego MAG, w celu wyznaczenia energii liniowej spawania hybrydy, zaproponowano zależność (1) uwzględniającą różne wartości współczynnika sprawności cieplnej: dla Plazmy $\eta=0,6$; dla MAG $\eta=0,8$

$$
E_{\text {hyb }}=\left(0,6 \cdot U_{p} \cdot I_{p}+0,8 \cdot U_{m} \cdot I_{m}\right) / V_{s} \quad[\mathrm{~J} / \mathrm{mm}]
$$

gdzie:

$\mathrm{E}_{\text {hyb }}$ - energia liniowa hybrydy Plazma+MAG;

$U_{p}, U_{m}$ - odpowiednio napięcie łuku plazmowego i łuku elektrycznego MAG [V];

$I_{p}, I_{m}$ - odpowiednio natężenie łuku plazmowego i łuku elektrycznego MAG $[A]$;

$\mathrm{V}_{\mathrm{s}}$ - prędkość spawania $[\mathrm{mm} / \mathrm{s}]$.

\section{Warunki spawania}

Złącza spawane, zostały wykonane na zrobotyzowanym stanowisku, powstałym w ramach projektu Inicjatywy EUREKA, przy współpracy firm SUPRA ELCO Jacek Szulc, Przemysłowego Instytutu Automatyki i Pomiarów „PIAP” w Warszawie oraz Zakładu Inżynierii Spajania Politechniki Warszawskiej. Spawane płyty próbne zostały wykonane z blach o wymiarach 350 × 150 × 10 mm. Uzyskano spoiny doczołowe $w$ pozycji podolnej (PA), jednym ściegiem. Do uformowania grani zastosowana została miedziana podkładka z oddzielnym chłodzeniem. Dane dotyczące właściwości mechanicznych stali S700 MC (zgodnie z PN-EN 10149-2) przedstawione zostały w tablicy I.

Ze względu na grubość spawanych blach $\mathrm{g}=10 \mathrm{~mm}$, przygotowanie złącza polegało na ukosowaniu krawędzi na Y z progiem $6 \mathrm{~mm}$ i pod kątem $15^{\circ} \mathrm{z}$ zachowaniem odstępu $\mathrm{b}=1,2 \mathrm{~mm}$. Zgodnie $z$ zaleceniami producenta SSAB stal Domex 700MC E może być spawana przy użyciu wszystkich dostępnych metod spawania (bez konieczności podgrzewania wstępnego). W celu uzyskania najwyższych wymagań wytrzymałościowych złączy wykonanych z tej stali, należy stosować materiały dodatkowe o wyższej wytrzymałości niż materiał podstawowy [10]. Zastosowano drut elektrodowy G 696 M21 Mn4Ni1 (nazwa handlowa ED-FK 800) o średnicy $1,2 \mathrm{~mm}$. Materiał ten jest dedykowany do spawania stali

Tablica I. Właściwości mechaniczne stali walcowanej termomechanicznie S700 MC wg PN-EN 10149-2

Table I. Mechanical properties of S700 MC steel according with EN 10149-2

\begin{tabular}{|c|c|c|c|}
\hline \multicolumn{4}{|c|}{ Właściwości mechaniczne } \\
\hline $\begin{array}{c}\text { Wytrzymałośćc } \\
\text { na rozciąganie } \\
\mathbf{R}_{\mathrm{m}}[\mathrm{MPa}]\end{array}$ & $\begin{array}{c}\text { Granica pla- } \\
\text { styczności } \\
\mathbf{R}_{\mathrm{e}}[\mathrm{MPa}]\end{array}$ & $\begin{array}{c}\text { Wydłużenie } \\
\mathbf{A}_{5}[\%]\end{array}$ & $\begin{array}{c}\text { Udarność } \\
{\left[\mathrm{J} / \mathrm{cm}^{2}\right]} \\
\left(-20^{\circ} \mathrm{C}\right)\end{array}$ \\
\hline 822 & 768 & 19 & 135 \\
\hline
\end{tabular}

niskostopowych o wysokiej wytrzymałości, a wytypowany został ze względu na jego wysoką wartość granicy plastyczności (porównywalną z granicą plastyczności materiału spawanego). Poniższe tablice zawierają dane dotyczące składu chemicznego materiału dodatkowego (tabl. II) oraz jego właściwości mechanicznych (tabl. III).

Tablica II. Skład chemiczny materiału dodatkowego ED-FK-800 Table II. Chemical composition of filler material ED-FK-800

\begin{tabular}{|c|c|c|c|c|c|c|}
\hline \multicolumn{7}{|c|}{ Skład chemiczny ED-FK 800 [\%] } \\
\hline C & Si & Mn & Cr & Ni & Mo & $\mathrm{Ti}$ \\
\hline 0,09 & 0,55 & 1,67 & 0,25 & 1,52 & 0,50 & 0,07 \\
\hline
\end{tabular}

Tablica III. Właściwości mechaniczne materiału dodatkowego ED-FK-800

Table III. Mechanical properties of filler material ED-FK-800

\begin{tabular}{|c|c|c|c|}
\hline \multicolumn{4}{|c|}{ Właściwości mechaniczne spoiny z drutu elektrodowego } \\
ED-FK 800
\end{tabular}

W zastosowanej hybrydowej metodzie spawania możliwości doboru parametrów nie są tak szerokie jak w przypadku metod konwencjonalnych. Jedynie w wąskim obszarze dostępnych parametrów otrzymuję się synergię źródeł ciepła obydwu metod użytych w hybrydzie. W związku z tym, zbyt duże zmiany jednego z parametrów spawania (np. natężenia prądu spawania) mogą- spowodować złą jakość spoiny.

Wykonano szereg prób poświęconych doborowi parametrów. W pierwszym etapie opracowano warunki umożliwiające uzyskanie właściwej geometrii spoin czołowych, wymagające synergicznego współdziałania obydwu metod w hybrydzie. W kolejnym etapie doboru parametrów opracowano warunki spawania z różną wartością energii liniowej (tabl. IV). Ze względu na wysoki stopień skomplikowania sterowania procesem hybrydowym, możliwe było spawanie jedynie $z$ dwiema różnymi wartościami energii liniowej spawania. Do badań właściwości mechanicznych złączy wytypowano zestawy parametrów C2 i C4. Podczas prób spawania stosowano następujące gazy, plazmotwórczy o handlowej nazwie Argon 4,5 (99,995\%) - gaz z grupy 11 wg PN-EN ISO 14175 oraz osłonowy - mieszanka osłonowa M21 (CORGON 18) zawierająca $20 \% \mathrm{CO}_{2}$ i $80 \% \mathrm{Ar}$.

\section{Badania metalograficzne}

W celu określenia właściwości złączy spawanych przeprowadzone zostały badania metalograficzne: makroi mikroskopowe oraz badania właściwości mechanicznych tj.:

- statyczna próba rozciągania złącza spawanego doczołowego wg PN-EN 10002-1:2004,

- próba technologiczna zginania złączy doczołowych wg PN-EN ISO 5173:2010,

- próba udarności spawanych złączy metalowych wg PN-EN 10045-1:1994,

- próba twardości metalowych złączy spawanych wg PN-EN ISO 6507-1:2007. 
Tablica IV. Parametry spawania złączy próbnych

Table IV. Welding parameters of testing joints

\begin{tabular}{|c|c|c|c|c|c|c|}
\hline $\begin{array}{c}\text { Oznaczenie } \\
\text { złącza }\end{array}$ & $\begin{array}{l}\text { Napięcie łuku } \\
\text { plazmowego } \\
\text { [V] }\end{array}$ & $\begin{array}{l}\text { Natężenie prądu } \\
\text { łuku plazmowego } \\
\text { [A] }\end{array}$ & $\begin{array}{c}\text { Napięcie łuku } \\
\text { MAG } \\
\text { [V] }\end{array}$ & $\begin{array}{l}\text { Natężenie prądu } \\
\text { łuku MAG } \\
\text { [A] }\end{array}$ & $\begin{array}{c}\text { Prędkość } \\
\text { spawania } \\
\text { [m/min] }\end{array}$ & $\begin{array}{c}\text { Energia liniowa } \\
\text { spawania } \\
\text { [kJ/mm] }\end{array}$ \\
\hline $\mathrm{C} 1$ & 30 & 350 & 26,3 & 272 & 0,55 & 1,311 \\
\hline $\mathrm{C} 2$ & 23,4 & 335,4 & 31,8 & 360,6 & 0,75 & 1,11 \\
\hline C4 & 23,9 & 332,4 & 33,6 & 390,7 & 0,95 & 0,96 \\
\hline C5 & 30 & 350 & 29,3 & 369 & 1 & 0,897 \\
\hline
\end{tabular}

Przygotowanie zgładów obejmowało klasyczne procedury szlifowania i polerowania, z końcowym trawieniem Nitalem 5\%. Obserwacje makroskopowe przeprowadzono na mikroskopie świetlnym Olympus. Obserwacje pod mikroskopem nie wykazały niezgodności spawalniczych. Zaobserwowano natomiast "wyjątkowość" obszaru strefy wpływu ciepła (SWC) polegającą na wystąpieniu podwójnej (dwupasmowej) strefy wpływu ciepła (rys. 2).

Badania mikrostruktury złączy wykazały, że zaobserwowana podczas badań makroskopowych podwójna strefa wpływu ciepła SWC1 i SWC2, charakteryzuje się różną wielkością ziaren, tablica V.

Struktura materiału rodzimego charakteryzuje się pasmowym ułożeniem ziaren z widocznymi odkształceniami plastycznymi będącymi efektem procesu kontrolowanego walcowania (wywołującego zgniot) z przyspieszonym chłodzeniem. Efekt ten, ze względu na wysoką temperaturę procesu spawania został utracony w SWC2 - jest to obszar o strukturze drobnoziarnistej, natomiast w SWC1 - w obszarze wysokotemperaturowym wystąpił znaczny rozrost ziaren. Podczas badań mikroskopowych zaobserwowano również wydzielenia o wielkości od kilku do kilkunastu $\mu \mathrm{m}$. Wg autora [1] jeśli wydzielenia mają ostre kształty, to są to węglikoazotki Ti, a wydzielenia z czarnym punktem w środku, prawdopodobnie wykrystalizowały na zanieczyszczeniach stali (nie blokują one granic ziaren).

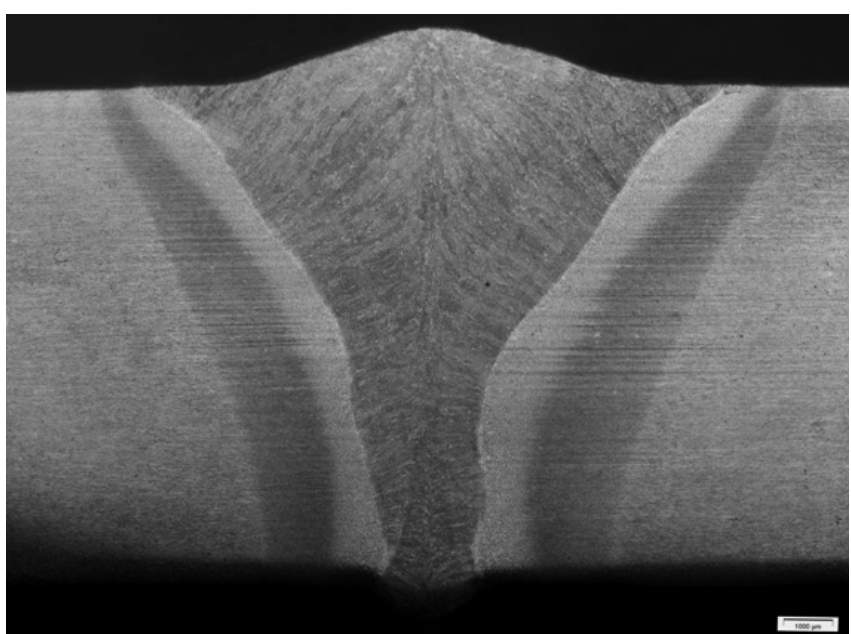

Rys. 2. Makrostruktura złącza C2

Fig. 2. Macrostructure of $\mathrm{C} 2$ welded joint

Pomiary twardości metodą Vickersa, z obciążeniem wgłębnika masą $100 \mathrm{~g}$, zostały wykonane na twardościo-

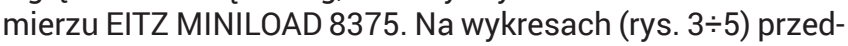
stawione zostały wartości średnie (każdego z punktów pomiarowych) oraz ich odchylenia standardowe z przyjętym 95\% poziomem ufności.

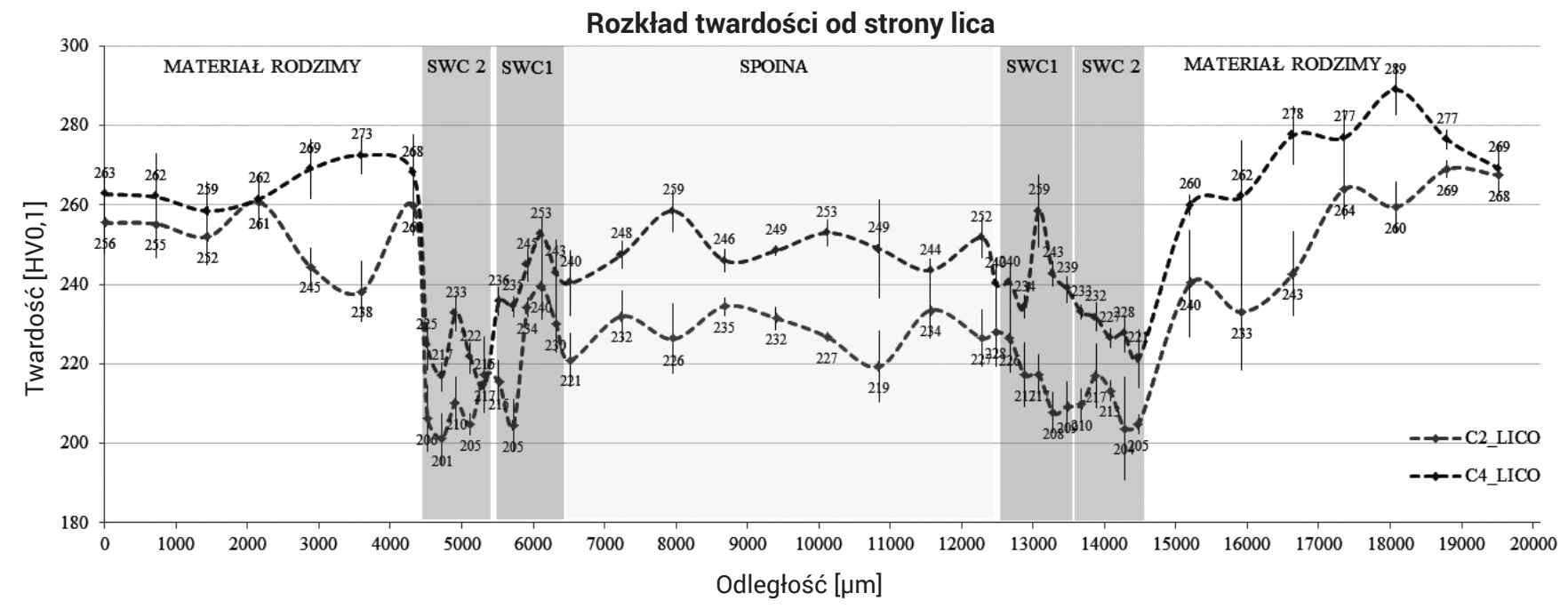

Rys. 3. Rozkład twardości w spoinie od strony lica

Fig. 3. Hardness distribution in welded joint (face side) 


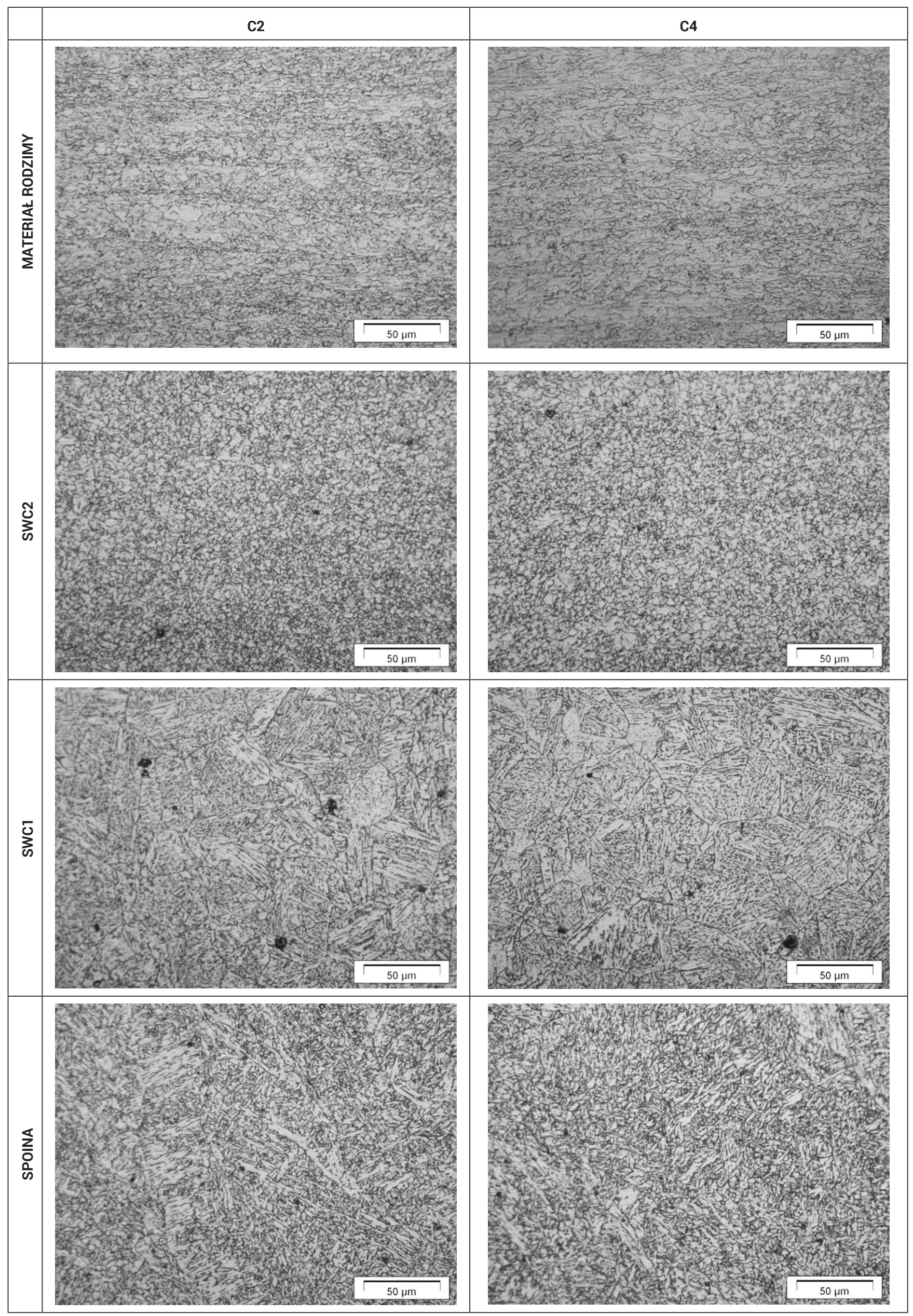




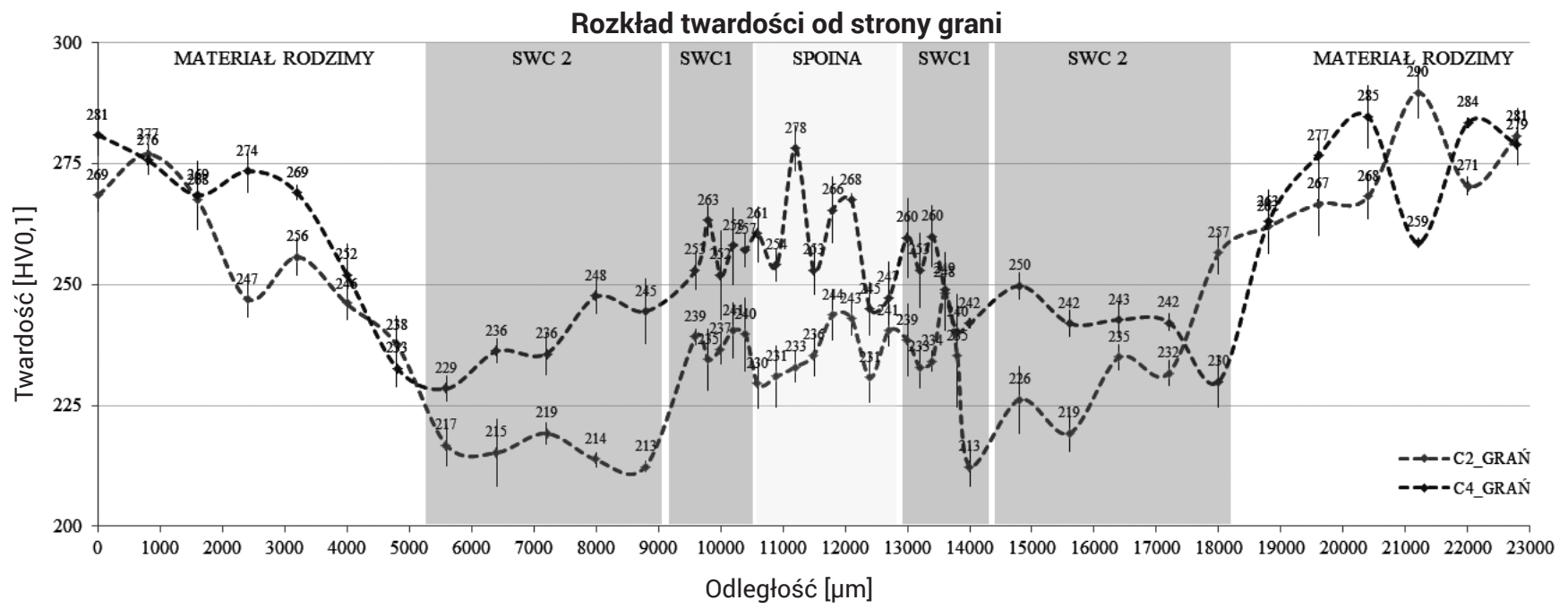

Rys. 4. Rozkład twardości w spoinie od strony grani

Fig. 4. Hardness distribution in welded joint (root side)

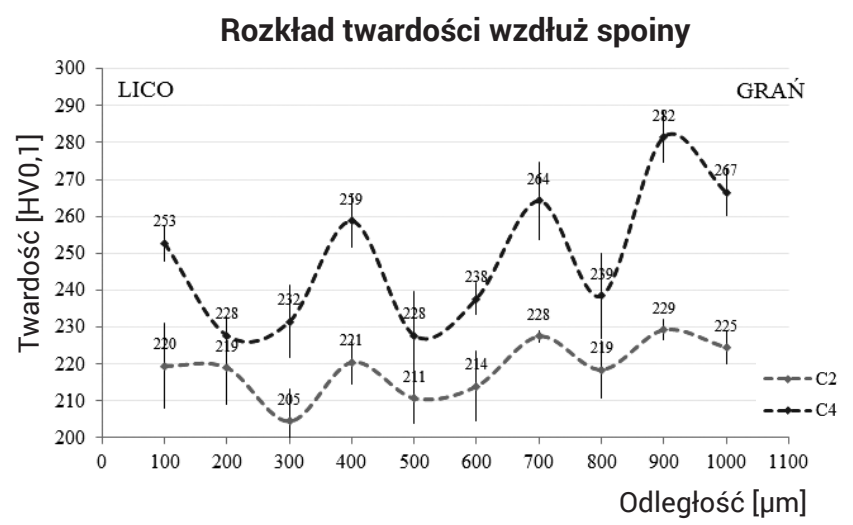

Rys. 5. Rozkład twardości w kierunku wysokości spoiny

Fig. 5. Hardness distribution in the height direction of the weld joint

Analizując przedstawione wykresy można zauważyć następujące zależności:

- porównanie rozkładów twardości C2 i C4, zarówno od strony lica jak i grani wykazało, że wyższą twardość (w każdym charakterystycznym obszarze złączy) wykazuje połączenie wykonane z niższą energią liniową spawania - złącze C4;

- zaobserwowano znaczące obniżenie twardości w strefie wpływu ciepła;

- obszarem charakteryzującym się największym zmiękczeniem jest SWC2;

- spadek średniej twardości (w stosunku do materiału rodzimego) zanotowano również w spoinie: w C2 o ok. 25 HV0,1, w C4 o ok. 15 HV0,1.

\section{Badania właściwości mechanicznych złączy}

W celu sprawdzenia wytrzymałości na rozciąganie badanych złączyzostała przeprowadzona statyczna próba rozciągania. Próbki zostały pobrane poprzecznie i ukształtowane w "wiosełka”, o przekroju (na długości roboczej) 14 x 10 mm. Dla poprawnego określenia miejsca zerwania, boki próbek wytrawiono Nitalem $30 \%$. Przyjęta prędkość rozciągania wynosiła $5 \mathrm{~mm} / \mathrm{min}$. Przeprowadzone próby nie wykazały wpływu wartości energii liniowej na wytrzymałość złącza na rozciąganie, ponieważ dla wszystkich próbek doraźna wytrzymałość na rozciąganie wyniosła ok. $770 \mathrm{MPa}$ (przy $\mathrm{R}_{\mathrm{m}}$ materiału spawanego na poziomie $822 \mathrm{MPa}$ ). Pomimo zastosowania materiału dodatkowego o wysokich właściwościach mechanicznych, wytrzymałość na rozciąganie złączy była na poziomie najniższej wartości $R_{m}$ (określonej przez producenta) materiału dodatkowego.

Podczas spawania metodą hybrydową Plazma+MAG, udział materiału rodzimego $\mathrm{w}$ spoinie jest na poziomie przekraczającym $50 \%$ - a więc, mogło dojść do znacznego zubożenia składu chemicznego spoiny. Poprawę jej wytrzymałości na rozciąganie można uzyskać np. poprzez dobór innego materiału dodatkowego.

Badane złącza zostały poddane próbie zginania poprzecznego z rozciąganiem od strony lica oraz od strony grani. Próby wykonano na stanowisku badawczym o max. obciążeniu $50 \mathrm{kN}$ z zastosowaniem trzpienia o średnicy $30 \mathrm{~mm}$ i odległością między rolkami równą $60 \mathrm{~mm}$. Zgodnie z zaleceniami PN-EN ISO 5173:2010 szerokość próbek wynosiła $40 \mathrm{~mm}$. W celu uniknięcia karbów koncentrujących naprężenia, lico oraz grań zostały zeszlifowane. Następnie dla określenia położenia osi spoiny oraz lica i grani boki próbek zostały wytrawione Nitalem $30 \%$. Na próbkach zginanych od strony lica nie zaobserwowano żadnych nieprawidłowości (rys. 6a), natomiast podczas zginania od strony grani na powierzchni obserwowano uskoki na liniach wtopienia (rys. 6b).

\section{Próba udarności}

W celu określenia wytrzymałości złączy na obciążenia dynamiczne, zostały przeprowadzone próby udarności. Wykonano je na młocie udarowym VEB Werkstoffprüfmachinen Leipzig. Stosowano energię początkową wahadła $300 \mathrm{~J}$. Próbki do badań przygotowano zgodnie z PN-EN 10045-1:1994 - pobrane zostały poprzecznie, a ich boki zeszlifowano oraz wytrawiono Nitalem $30 \%$. Na powierzchni od strony lica, został nacięty karb typu V - odpowiednio w SWC lub w spoinie. Następnie próbki zostały skrócone na wymiar $55 \mathrm{~mm}$ (tak aby nacięty karb znajdował się w osi symetrii próbek). Próby udarności zostały przeprowadzone w warunkach takich jak w pracy [1], której wyniki traktowano jako odniesienie. $\mathrm{W}$ tablicy $\mathrm{VI}$ zestawiono wyniki pomiarów pracy łamania $\mathrm{K}$ (w temp. $-30{ }^{\circ} \mathrm{C}$ ) przedstawiając średnią arytmetyczną z czterech pomiarów, odchylenie standardowe od wartości średniej oraz obliczono udarność. Przełomy próbek zbadano również pod mikroskopem świetlnym Olympus. Zdjęcia przełomów przedstawiono na rysunku 7. 
a)

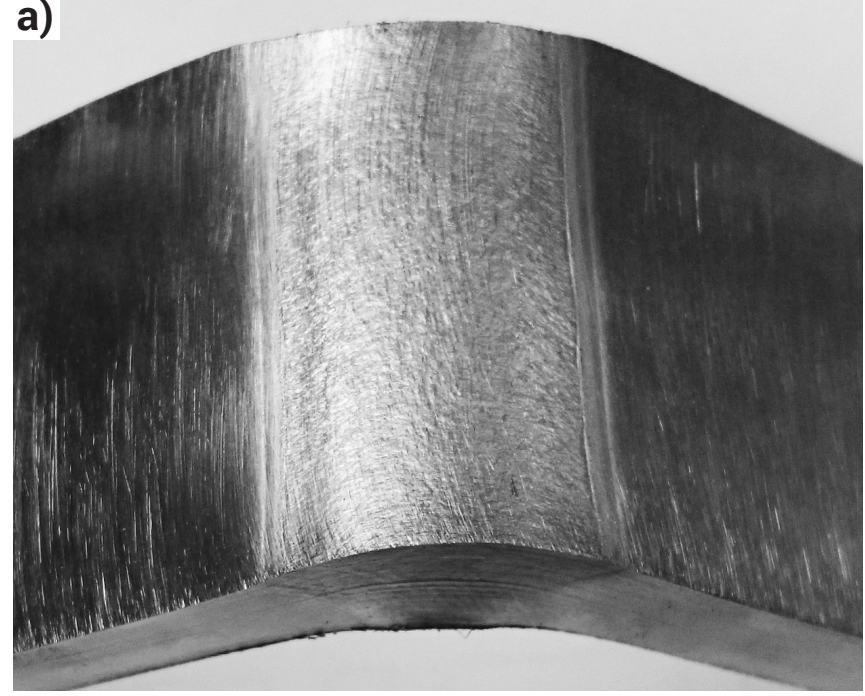

Rys. 6. Widok spoin po próbie gięcia: a) lico spoiny, b) grań spoiny

Fig. 6. View of joint after bending test: a) face side, b) root side

a)

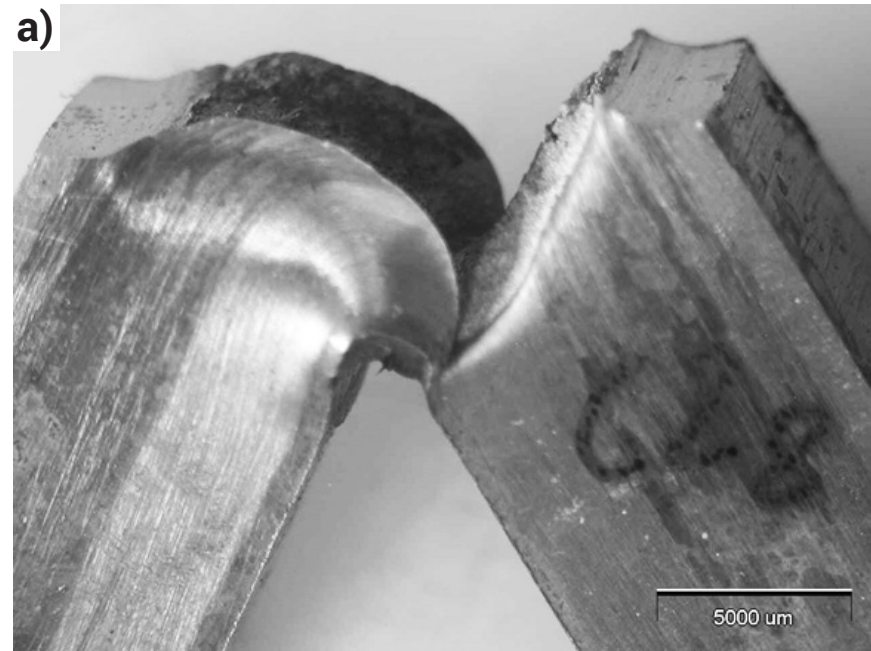

b)

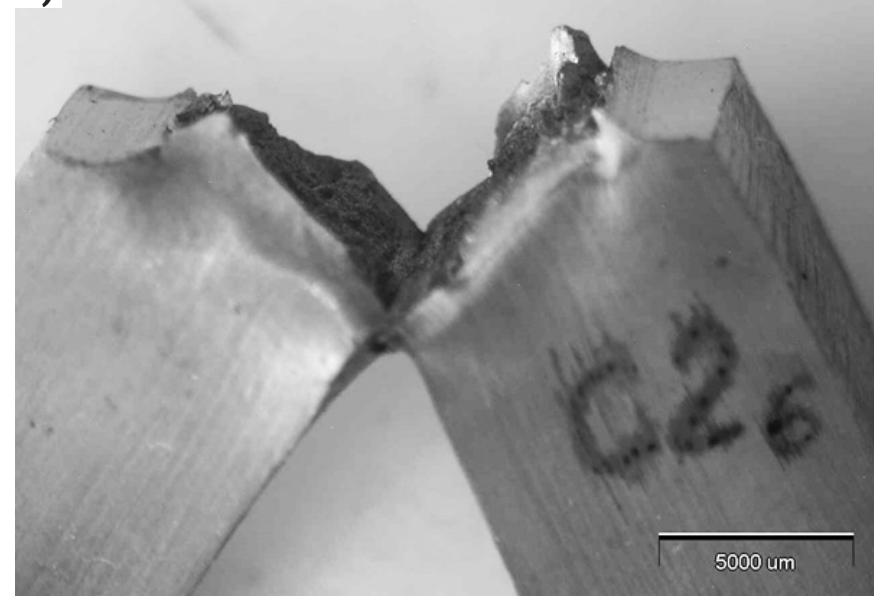

b)

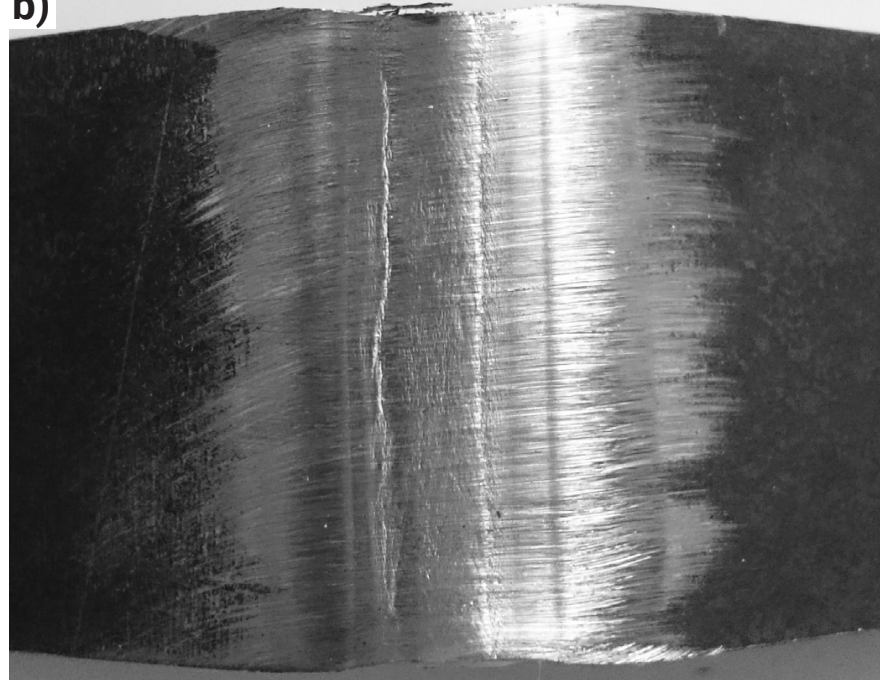

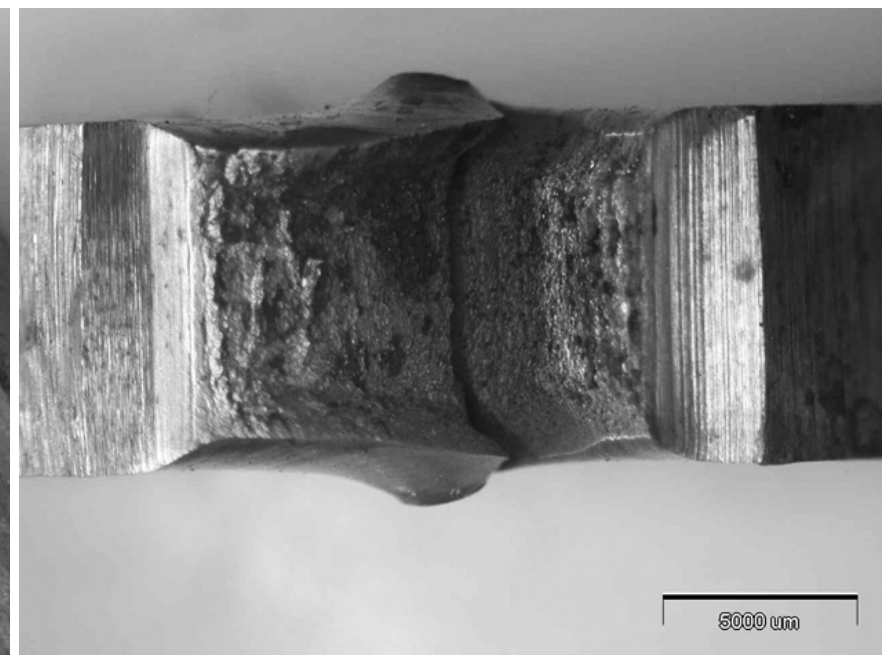

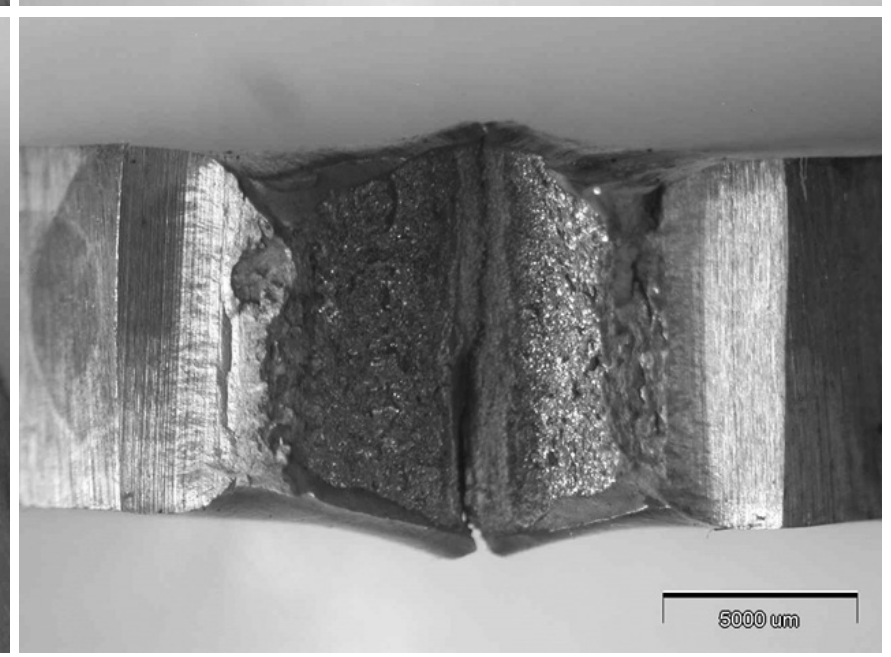

Rys. 7. Widok próbek po teście udarności: a) SWC, b) spoina

Fig. 7. View of sampels after impact test: a) HAZ, b) joint

Na podstawie zdjęć przełomów próbek można stwierdzić, że przełomy próbek z karbem naciętym w SWC są mieszane z rozwarstwieniem, natomiast te z karbem w spoinie są rodzaju kruchego. Przełamane próbki charakteryzują się drobnoziarnistą mikrostrukturą.

Uzyskane wartości KCV są nadzwyczaj wysokie.

Analiza wyników wykazała, że:

- w badanych złączach stwierdzono wyższą udarność w SWC niż w spoinie, co stanowi przeciwieństwo do właściwości złączy spawanych metodami konwencjonalnymi, opisane w literaturze;

- wyższą udarność wykazuje złącze wykonane wyższą energią liniową spawania, zawierające mniejszy udział materiału rodzimego w spoinie - złącze C2. 
Tablica VI. Wyniki próby udarności w temperaturze $-30{ }^{\circ} \mathrm{C}$

Table VI. Results after impact test in temperatue $-30^{\circ} \mathrm{C}$

\begin{tabular}{|c|c|c|c|c|}
\hline Złącze & Obszar złącza & $\begin{array}{c}\text { Praca tamania } \\
\bar{x} \text { K [J] }\end{array}$ & $\begin{array}{c}\text { Odchylenie standardowe } \\
\text { s }\end{array}$ & $\begin{array}{c}\left.\text { Udarność KCV (-30 }{ }^{\circ} \mathbf{C}\right) \\
{\left[\mathbf{J} / \mathbf{c m}^{2}\right]^{*}}\end{array}$ \\
\hline C2 & SWC & 162 & 28,8 & 203 \\
\hline C2 & SPOINA & 93 & 15,97 & 117 \\
\hline C4 & SWC & 135 & 30,59 & 169 \\
\hline C4 & SPOINA & 79 & 11,1 & 99 \\
\hline * pole powierzchni próbki (w miejscu karbu) $S_{0}=0,80 \mathrm{~mm}^{2}$
\end{tabular}

\section{Podsumowanie i wnioski}

Celem pracy było zbadanie wpływu wartości energii liniowej spawania na jakość złączy doczołowych stali S700 MC wykonanych metodą spawania hybrydowego Plazma+MAG. W celu zweryfikowania wpływu parametru na jakość oraz właściwości mechaniczne złączy C2 i C4, przeprowadzono badania niszczące. Zgodnie z normami spreparowano próbki, które zostały poddane badaniom metalograficznym: makro- i mikroskopowym oraz próbom twardości, statycznego rozciągania, zginania i udarności. Analiza wyników przeprowadzonych badań umożliwia sformułowanie następujących wniosków:

1. Możliwe jest wykonanie pełnowartościowego złącza spawanego metodą hybrydową Plazma+MAG stali S700 MC jednościegowo.

2. Zaobserwowano „podwójną” strefę wpływu ciepła (różniącą się mikrostrukturą i twardością) SWC1 i SWC2.

3. W strefie wpływu ciepła zarejestrowano spadek średniej twardości w złączu spawanym.

4. Niezależnie od wartości energii liniowej spawania, w SWC1 odnotowano mniejszy niż w SWC2 spadek twardości.

5. W złączach spawanych wykonanych z wyższą wartością energii liniowej spawania (C2) zarejestrowano niższą średnią twardość w SWC2 (209 HV0,1), niż w złączach wykonanych niższą wartością energii liniowej spawania (C4), dla której średnia twardość w SWC2 wyniosła 225 HV0,1.

6. Spadek średniej twardości w złączu, zależny jest od wartości energii liniowej spawania - złącze wykonane z niższą wartością energii liniowej charakteryzowało mniejszym spadkiem twardości.

7. Próby statycznego rozciągania oraz zginania wykazały, że występowanie w złączu obszaru zmiękczonego nie decyduje o zmniejszeniu jego właściwości wytrzymałościowych.

8. Udarność KCV złącza zależny od wartości energii liniowej spawania. W przypadku zastosowanej metody hybrydowej Plazma+MAG wyższą udarnością charakteryzuje się złącze wykonane wyższą energią liniową spawania (C2).

9. Niezależnie od wartości energii liniowej (w próbach przeprowadzonych w ujemnej temperaturze) w badanych złączach stwierdzono wyższą udarność w SWC niż w spoinie, co stanowi przeciwieństwo do właściwości złączy spawanych metodami konwencjonalnymi (np. TIG, MAG, SAW, MMA).

10. Udarność w SWC jest nadzwyczaj wysoka. Może to być efektem podwójnego cyklu cieplnego i dwustrefowego obszaru SWC - wymaga to dalszego wyjaśnienia poprzez kolejne badania naukowe.

\section{Literatura}

[1] Górka J.: Właściwości i struktura złączy spawanych stali obrabianej termomechanicznie o wysokiej granicy plastyczności, Monografia, Wydawnictwo Politechniki Śląskiej, Gliwice 2013.

[2] Górka J.: Właściwości spoin stali obrabianych termomechanicznie o wysokiej granicy plastyczności, Przegląd Spawalnictwa Vol. 83, Nr 12, s. 31-35, 2011.

[3] Górka J.: Stal obrabiana termomechanicznie S700 MC i jej spawalność, Biuletyn Instytutu Spawalnictwa 6/2012.

[4] Tasak E., Ziewiec A.: Spawalność materiałów konstrukcyjnych. Tom 1 Spawalność stali, Wydawnictwo JAK, Kraków 2009.

[5] red. J. Pilarczyk: Poradnik inżyniera, Spawalnictwo t.1, WNT, Warszawa 2013.

[6] Szulc J., Chmielewski T., Pilat Z.: Zrobotyzowane spawanie hybrydowe Plazma + MAG stali S700 MC, Przegląd Spawalnictwa Vol. 88, Nr 1, s. $41-45,2016$.
[7] Szulc J., Chmielewski T., Węglowski M.: Wybrane możliwości technologiczne hybrydowej metody spawania Plasma-MAG, Przegląd Spawalnictwa Vol. 88, Nr 5,2016, s. 89-92.

[8] Górka J., Stano S: Właściwości i struktura złączy spawanych hybrydowo HLAW (wiązka laserowa - FCAW) stali obrabianej termomechanicznie S700 MC, Przegląd Spawalnictwa Vol. 87,Nr 5, 2015, s. 52-56.

[9] Chmielewski T., Szulc J., Pilat Z.: Badania metalograficzne spoin wykonanych hybrydową metodą PTA-MAG, Przegląd Spawalnictwa Nr 7, 2014, s. $46-50$.

[10] www.ssab.com, charakterystyka materiału DOMEX $700 \mathrm{MC}$ (http://www.aedmotorsport.com/docs/a09-domex-700-high-strengthsteel-sheet-specs.pdf) 